\title{
Isolasi Bakteri dan Karakterisasi Protease dari Sumber Air Rawa Indralaya
}

\author{
Ace Baehaki*), Rinto dan Agus Ramiadi \\ Program Studi Teknologi Hasil Perikanan, Fakultas Pertanian Universitas Sriwijaya, Palembang 30662 \\ Diterima 10-06-2009 Disetujui 06-02-2012
}

\begin{abstract}
The aim of this study was to bacteria isolation and characterization proteases from water swamp. The water swamp samples collected from Indralaya for microbial isolation. Three isolates showed proteolytic index $>1.00$. The optimum pH of extraceluller proteases from A6S3, $\mathrm{A} 4 \mathrm{~S} 3$ and $\mathrm{A} 15 \mathrm{~S} 3$ were $7.5 ; 8.0 ; 8.0$, respectively. The optimum temperature of $\mathrm{A} 6 \mathrm{~S} 3, \mathrm{~A} 4 \mathrm{~S} 3$ and $\mathrm{A} 15 \mathrm{~S} 3$ protease were $40 ; 50 ; 50{ }^{\circ} \mathrm{C}$, respectively. Effect of metal ion ( Fe, K, Mn, and $\mathrm{Zn}$ ) shown $\mathrm{Fe}$ and $\mathrm{K}$ were inhibit protease A6S3, all metal ion were inhibit protease A4S3 and $\mathrm{K}, \mathrm{Mn}$ and $\mathrm{Zn}$ inhibit protease A15S3. Study on the effect of metals ion and spesific inhibitors indicated that all protease were metaloprotease. Their moleculer weights were determined by using SDS-PAGE and zymogram technique for A6S3 isolate were 70, 88 , 106 and $121 \mathrm{kD}$ respectively. Whereas for isolate A4S3 was $138 \mathrm{kD}$ and isolate A15S3 was $131 \mathrm{kD}$.
\end{abstract}

Keywords: bacteria, protease, swamp

\begin{abstract}
ABSTRAK
Tujuan penelitian ini adalah melakukan isolasi bakteri dan karakterisasi protease dari air rawa. Sampel air rawa diambil dari daerah Indralaya untuk dilakukan isolasi mikroba. Tiga isolat menunjukkan indeks proteolitik >1,0. pH optimum protease ekstraselular dari A6S3, A4S3 dan A15S3 masing-masing adalah 7,5; 8,0 dan 8,0. Suhu optimum protease A6S3, A4S3 dan A15S3 masing-masing adalah 40; 50 dan 50 ${ }^{\circ}$ C. Pengaruh ion logam ( Fe, K, Mn dan Zn) menunjukkan Fe dan K menghambat protease A6S3, semua ion logam menghambat protease A4S3 dan ion logam K, Mn dan Zn menghambat protease A15S3. Penelitian pengaruh ion logam dan inhibitor spesifik mengindikasikan bahwa semua protease isolat air rawa adalah metaloprotease. Berat molekul yang ditentukan menggunakan SDS-PAGE dan zimogram menunjukkan bahwa isolat A6S3 memiliki berat molekul 70, 88, 106, dan $12 \mathrm{kD}$. Isolat A4S3 memiliki berat molekul $138 \mathrm{kD}$ dan isolat A15S3 memiliki berat molekul $131 \mathrm{kD}$.
\end{abstract}

Kata Kunci: bakteri, protease, rawa

\section{PENDAHULUAN}

Enzim merupakan salah satu produk alami yang memegang peranan penting dalam berbagai aplikasi industri, mulai dari proses pengolahan makanan sampai produk bahan kimia berharga. Sebenarnya enzim bukan hal yang baru di kalangan masyarakat karena secara tradisional telah digunakan sejak dahulu kala, seperti dalam pembuatan keju, penyamakan kulit dan pelunakan daging (Van der Oost \& de Graaf 2003).

Protease adalah enzim yang menghidrolisis ikatan peptida pada protein. Untuk melakukan aktivitasnya, protease membutuhkan air sehingga dikelompokkan ke dalam kelas hidrolase. Protease berperan dalam sejumlah reaksi biokimia seluler. Selain diperlukan untuk degradasi senyawa protein nutrien, protease terlibat dalam sejumlah mekanisme

\footnotetext{
*Telp: +6287770070225

e-mail: ace76_none@yahoo.com
}

patogenisitas, sejumlah proses pasca translasi protein, dan mekanisme ekspresi protein ekstraseluler (Rao et al. 1998).

Enzim protease berguna untuk kebutuhan industri seperti untuk deterjen, pasta gigi, industri penyamakan kulit, medis dan lain-lainnya. Salah satu sumber enzim protease adalah dari mikroba. Penelitian mikroba sebagai sumber alami penghasil enzim ini sudah banyak dilakukan, akan tetapi penelitian mikroba dengan habitat tertentu seperti dari rawa masih sedikit. Daerah rawa merupakan ekosistem yang memiliki keanekaragaman mikroba yang tinggi sehingga memungkinkan terdapatnya mikroba penghasil protease. Daerah rawa yang memiliki $\mathrm{pH}$ rendah diharapkan menghasilkan karakteristik protease yang unik untuk diaplikasikan pada industri. Penelitian enzim protease dari mikroba rawa, penting untuk dilakukan sebagai alternatif baru sebagai sumber penghasil enzim, mengingat daerah Indralaya 
Sumatera Selatan memiliki daerah rawa yang sangat luas yang tentunya terdapat mikroba penghasil protease.

\section{BAHANDANMETODE}

Isolasi Bakteri Rawa Isolasi bakteri rawa dilakukan dengan mengambil sampel air rawa dari daerah Indralaya secara aseptik. Sampel diencerkan dari $10^{-1}$ sampai $10^{-5}$, sebanyak 0,1 ml dari hasil pengenceran disebar pada medium Luria Bertani (LB) Agar untuk mendapatkan biakan murni, selanjutnya diinkubasi pada suhu $37^{\circ} \mathrm{C}$.

Uji Proteolitik. Hasil dari isolasi mikroba dilakukan uji proteolitik untuk melihat apakah mikroba ini menghasilkan enzim protease atau tidak. Uji proteolitik dilakukan dengan menggunakan medium Skim Milk Agar (SMA), isolat dari bakteri yang berasal dari air rawa ditusukan dalam medium, selanjutnya diinkubasi selama 24 jam pada suhu $37^{\circ} \mathrm{C}$. Aktivitas proteolitik dari bakteri rawa yang ditumbuhkan pada medium SMA ditunjukan dengan terlihatnya areal bening yang muncul di sekitar koloni yang terbentuk. Indeks proteolitik dihitung dengan cara diukur diameter areal bening dan dibandingkan dengan diameter koloni bakteri.

Produksi Protease. Mikroba diinokulasi sebanyak 1-2 lup pada medium LB dengan komposisi tripton $1 \%$, $\mathrm{NaCl} 1 \%$ dan yeast extract $0,5 \%$. Proses diawali dengan penentuan umur prekultur (dalam medium LB) yang tepat untuk keperluan produksi enzim. Pengamatan dilakukan dengan mengukur optical density (OD) sampai nilai $\mathrm{OD}=0,8$ pada $\lambda=620 \mathrm{~nm}$. Medium LB yang sudah mempunyai $\mathrm{OD}=0,8$ diambil $10 \%$ kemudian ditambahkan pada medium LB yang baru sebagai medium untuk memproduksi protease. Pada medium LB ini diukur nilai OD, aktivitas protease dan kadar protein setiap 8 jam selama 56 jam. Untuk memisahkan sel dilakukan sentrifugasi dengan kecepatan $3000 \mathrm{rpm}$ selama 15 menit pada suhu $4^{\circ} \mathrm{C}$.

Pengukuran Aktivitas Protease. Aktivitas protease diukur dengan metode Bergmeyer et al. (1983), dengan menggunakan substrat kasein Hammerstein $2 \%$ (b/v). Satu unit aktivitas protease didefinisikan sebagai jumlah enzim yang dapat menghasilkan satu mol produk tirosin per menit pada kondisi pengukuran.

Karakterisasi Protease Ekstrak Kasar. Uji karakterisasi protease yang meliputi pengaruh $\mathrm{pH}(6,5 ; 7$; $7,5 ; 8 ; 8,5 ; 8,5 ; 9)$, suhu $\left(30^{\circ} \mathrm{C} ; 40^{\circ} \mathrm{C} ; 50^{\circ} \mathrm{C} ; 60^{\circ} \mathrm{C} ; 70^{\circ} \mathrm{C}\right)$, ion logam $\left(\mathrm{K}^{+} ; \mathrm{Fe}^{2+} ; \mathrm{Mn}^{2+}\right.$ dan $\left.\mathrm{Zn}^{2+}\right)$ dan inhibitor spesifik (EDTA).
SDS PAGE dan Zimogram. Penentuan berat molekul dilakukan menggunakan SDS PAGE (Laemmli 1970). Sedangkan zimogram menggunakan modifikasi metode Choi et al. (2001). Gel akrilamid 8\% dikopolimerisasi dengan substrat kasein $2 \%$. Setelah gel dilakukan elektroforesis, gel direndam dengan Triton X-100 2,5\% selama 1 jam dan dilakukan inkubasi dalam buffer Tris- $\mathrm{Cl} 10 \mathrm{mM}$, pH 8 selama 24 jam. Pewarnaan dengan silver staining yaitu : gel direndam dalam larutan fiksasi ( $25 \%$ metanol dan $12 \%$ asam asetat) selama 1 jam kemudian direndam dalam $50 \%$ etanol selama 20 menit, kemudian diganti dengan $30 \%$ etanol selama 2 × 20 menit, larutannya diganti dengan enhancer kemudian dicuci dengan akuadestilata setelah dicuci ditambahkan larutan silver nitrat selama 30 menit kemudian dicuci lagi dengan akuadestilata 2 × 20 detik dan ditambahkan larutan campuran $\mathrm{Na}_{2} \mathrm{CO}_{3}$ dan formaldehida dan terakhir dengan larutan fiksasi.

\section{HASIL DAN PEMBAHASAN}

\section{Isolasi dan Uji Proteolitik Bakteri Penghasil}

Protease. Proses isolasi didapatkan 34 isolat, dari isolatisolat ini kemudian diuji indeks proteolitiknya untuk selanjutnya isolat ini diproduksi untuk menghasilkan protease. Hasil uji proteolitik bakteri dari rawa Indralaya terpilih untuk dianalisa aktivitas protease dapat dilihat pada Tabel 1.

Produksi Protease dari Bakteri Air Rawa. Hasil produksi protease dari bakteri air rawa ini dapat dilihat pada Gambar 1. Produksi protease dari bakteri air rawa memiliki waktu produksi optimum untuk isolat A4S3, A6S3 dan A15S3 adalah 48 jam. Protease isolat A6S3 memiliki aktivitas tertinggi $(0,528 \mathrm{IU} / \mathrm{ml})$ setelah diinkubasi selama 48 jam dalam medium LB, protease diproduksi seiring dengan pertumbuhan sel dan mencapai aktivitas tertinggi pada fase stasioner (Gambar 1 A). Pada Gambar 1 B tampak bahwa protease isolate A4S3 memiliki aktivitas tertinggi $(0,517 \mathrm{IU} / \mathrm{ml})$ setelah diinkubasi selama 48 jam, protease diproduksi pada fase menjelang penurunan. Untuk protease isolat A15S3 memiliki waktu produksi optimum yang sama dengan isolat $\mathrm{A} 6 \mathrm{~S} 3$ dan A4S3 yaitu selama 48 jam dengan aktivitas tertinggi 0,528 IU/ml (Gambar 1C).

\begin{tabular}{|c|c|c|}
\hline Asal bakteri & Isolat & Indeks proteolitik \\
\hline \multirow{3}{*}{ Air rawa } & A6S3 & 1,5 \\
\hline & A4S3 & 1,2 \\
\hline & $\mathrm{A} 15 \mathrm{~S} 3$ & 1,1 \\
\hline
\end{tabular}


Penelitian lain pada protease bakteri didapatkan bakteri dengan waktu produksi protease optimum yang sama dengan protease isolat rawa (48 jam) adalah B. subtilis PE-11 (Adinarayana et al. 2003) dan B. licheniformis Lbbl11 (Olajuyigbe \& Ajele 2008). B. subtilis CN2 memiliki waktu produksi optimum selama 14 jam (Tran \& Nagano 2002), dan B. SMIA-2 memiliki aktivitas optimum pada jam ke 9 (Nascimento \& Martins 2004).

Karakterisasi Protease Ekstrak Kasar. Pengaruh pH. Semua reaksi enzimatis dipengaruhi $\mathrm{pH}$, sehingga diperlukan bufer untuk mengontrol $\mathrm{pH}$ reaksi. Pada umumnya

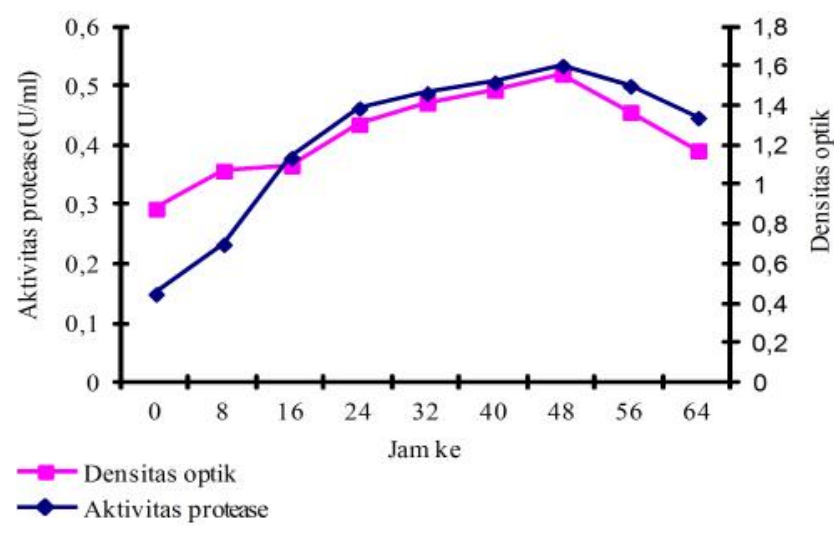

A
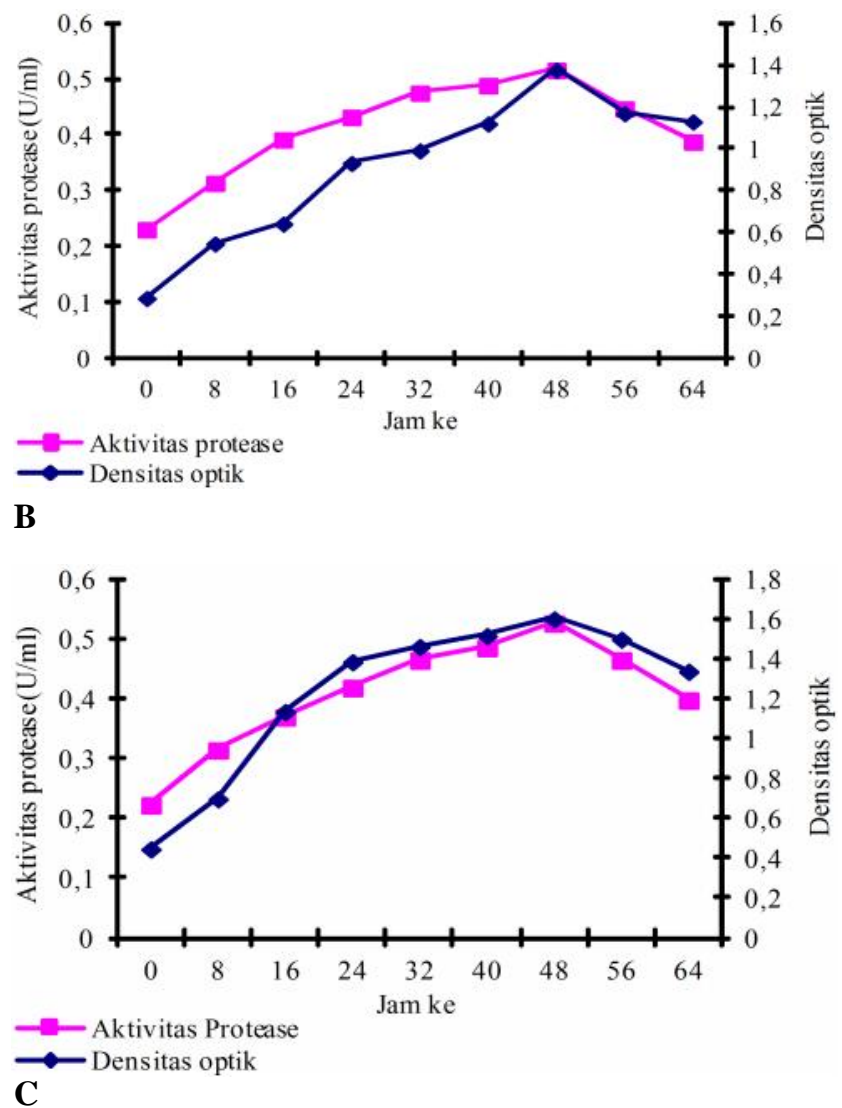

$\mathbf{C}$

Gambar 1 Produksi optimum protease bakteri air rawa $(\mathrm{A}=\mathrm{isolat}$ $\mathrm{A} 6 \mathrm{~S} 3, \mathrm{~B}=\mathrm{A} 4 \mathrm{~S} 3$ dan $\mathrm{C}=\mathrm{A} 15 \mathrm{~S} 3$ ) enzim bersifat amfolitik, yang berarti enzim mempunyai konstanta disosiasi pada gugus asam maupun gugus basanya terutama pada gugus residu terminal karboksil dan gugus terminal aminonya. Diperkirakan perubahan keaktifan enzim akibat ionisasi pada gugus ionik enzim, pada sisi aktifnya atau sisi lain yang secara tidak langsung mempengaruhi sisi aktif. Gugus ionik berperan dalam menjaga konformasi sisi aktif dalam mengikat substrat dan dalam mengubah substrat menjadi produk. Ionisasi juga dapat dialami oleh substrat atau kompleks enzim-substrat, yang juga berpengaruh terhadap aktivitas enzim (Muchtadi et al. 1996). Perubahan pH yang kasar enzim dapat mengalami denaturasi akibat gangguan terhadap berbagai interaksi non kovalen yang menjaga kestabilan struktur 3D enzim (Hames \& Hooper 2000). Gambar 2 memperlihatkan pH optimum aktivitas protease ekstrak kasar bakteri air rawa.

Protease isolat A6S3 dan A15S3 memiliki pH optimum pada pH 8 (Gambar 2), sedangkan isolat A4S3 memiliki pH optimum pada pH 7,5 (Gambar 2). Protease yang memiliki pH optimun yang sama dengan protease isolat A6S3 dan A15S3 adalah protease dari bakteri Bacillus licheniformis Lbbl-11 (Olajuyigbe \& Ajele 2008), dan B. sp. (Nascimento \& Martins 2004). Protease dari Alcaligenes faecalis memiliki pH optimum yang lebih tinggi dibandingkan dengan proteasea dari isolat air rawa yaitu pada pH 9 (Thangam \& Rajkumar 2002), begitu juga dengan protease dari Halobacillus sp. SR5-3 memiliki pH optimum pada $\mathrm{pH}$ yang tinggi yaitu pada pH 10 (Namwong et al. 2006).

Pengaruh Suhu. Pada umumnya setiap enzim memiliki aktivitas maksimum pada suhu tertentu, aktivitas enzim akan semakin meningkat dengan bertambahnya suhu sampai suhu optimum tercapai. Setelah itu kenaikan lebih lanjut akan menyebabkan aktivitas enzim menurun. Pengaruh suhu terhadap aktivitas protease ekstrak kasar bakteri isolat air rawa terdapat pada Gambar 3.

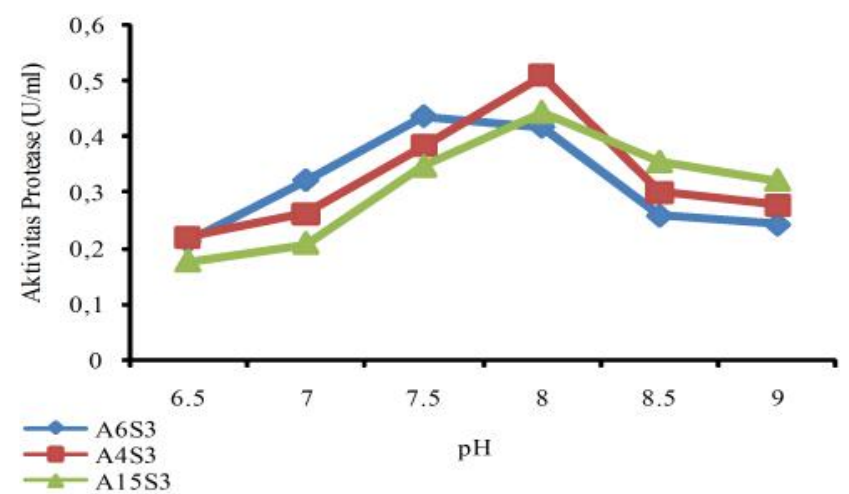

Gambar 2 Pengaruh pH pada protease dari bakteri air rawa 
Hasil pengukuran aktivitas enzim pada berbagai suhu, suhu optimum protease bakteri isolat A6S3 dan A15S3 dengan suhu inkubasi $50^{\circ} \mathrm{C}$ (Gambar 3), sedangkan isolat A4S3 memiliki suhu optimum $40^{\circ} \mathrm{C}$. Protease Halobacillus sp. SR5-3 yang memiliki suhu optimum yang sama dengan protease isolat A6S3 dan A15S3 yaitu pada suhu $50^{\circ} \mathrm{C}$ (Namwong et al. 2006). Protease B. laterosporus memiliki suhu optimum yang sama dengan isolat $\mathrm{A} 4 \mathrm{~S} 3$ yaitu pada suhu $40^{\circ} \mathrm{C}$ (Usharani \& Muthuraj 2010). Suhu optimum isolat dari rawa ini dibandingkan dengan protease Yersinia ruckeri (Secades \& Guijarro 1999), memiliki suhu optimum lebih tinggi, protease tersebut memiliki suhu optimum $37^{\circ} \mathrm{C}$. Suhu optimum protease isolat rawa dibandingkan dengan protease $B$. PE-11 (Adinarayana et al. 2003) dan B. sp.(Nascimento \& Martins 2004), memiliki suhu optimum yang lebih rendah, suhu optimum $B$. PE-11 dan $B$. sp. adalah $60^{\circ} \mathrm{C}$.

Suhu mempengaruhi laju reaksi katalisis enzim dengan dua cara. Pertama, kenaikan suhu akan meningkatkan energi molekul substrat dan pada akhirnya meningkatkan laju reaksi enzim. Peningkatan suhu juga berpengaruh terhadap perubahan konformasi substrat sehingga sisi aktif substrat mengalami hambatan untuk memasuki sisi aktif enzim dan menyebabkan turunnya aktivitas enzim. Kedua, peningkatan

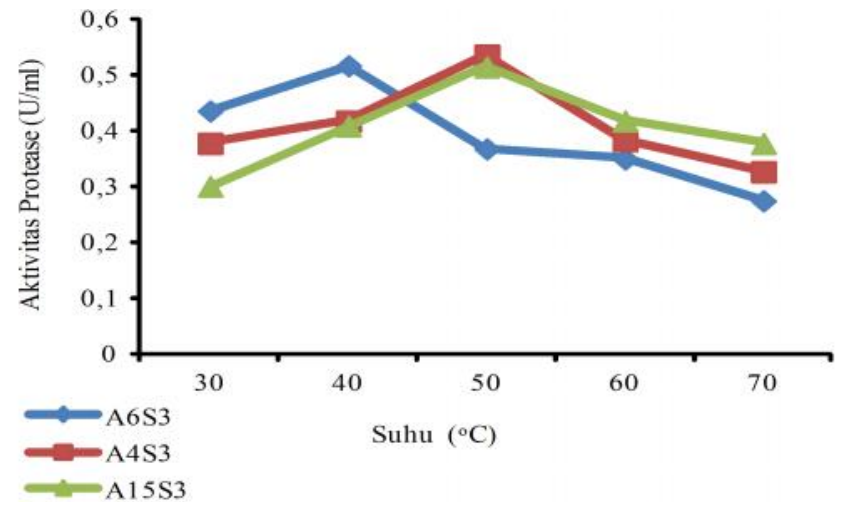

Gambar 3 Pengaruh suhu pada protease dari bakteri air rawa energi termal molekul yang membentuk struktur protein enzim itu sendiri akan menyebabkan rusaknya interaksi-interaksi non kovalen (ikatan hidrogen, ikatan Van der Walls, ikatan hidrofobik dan interaksi elektrostatik) yang menjaga struktur 3D enzim secara bersama-sama sehingga enzim mengalami denaturasi. Denaturasi menyebabkan struktur lipatan enzim membuka pada bagian permukaannya sehingga sisi aktif enzim berubah dan mengakibatkan terjadi penurunan aktivitas enzim (Hames \& Hooper 2000).

Pengaruh Ion Logam dan Inhibitor Spesifik. Beberapa enzim membutuhkan ion logam sebagai kofaktor untuk mendukung efisiensi katalitik enzim. Logam tersebut membantu reaksi katalitik dengan cara mengikat substrat pada sisi pemotongan. Selain berperan dalam pengikatan enzim dengan substrat, beberapa logam juga dapat mengikat enzim secara langsung untuk menstabilkan konformasi aktifnya atau menginduksi formasi situs pengikatan atau situs aktif suatu enzim. Gambar 4 memperlihatkan pengaruh ion logam terhadap aktivitas protease bakteri isolat air rawa.

Inhibitor ion logam yang kuat terhadap protease adalah $\mathrm{Fe}^{2+}(1 \mathrm{mM})$ dan $\mathrm{K}^{+}$pada isolat A6S3 (Gambar 4A), sedangkan protease isolat $\mathrm{A} 4 \mathrm{~S} 3$ inhibitor kuat adalah semua ion logam dengan konsentrasi $1 \mathrm{mM}$ (Gambar $4 \mathrm{~B}$ ). Untuk protease isolat A15S3 (Gambar $4 \mathrm{C}$ ) inhibitor kuatnya adalah $\mathrm{K}$ (1 dan $5 \mathrm{mM})$, Mn (1 dan $5 \mathrm{mM}$ ) dan Zn (1 dan $5 \mathrm{mM}$ ). Oleh karena dipengaruhi ion logam, maka protease digolongkan metaloprotease. Penghambatan ion logam terhadap aktivitas protease pada konsentrasi tertentu berkaitan dengan kekuatan ion, dimana kekuatan ion itu sendiri mempengaruhi konformasi atau struktur tiga dimensi dari protein enzim atau protein substrat (Suhartono 1989). Pada konsentrasi tertentu ion logam tertentu dapat bertindak sebagai inhibitor, tetapi dapat juga bertindak sebagai aktivator pada konsentrasi lain (Richardson \& Hyslop 1985).

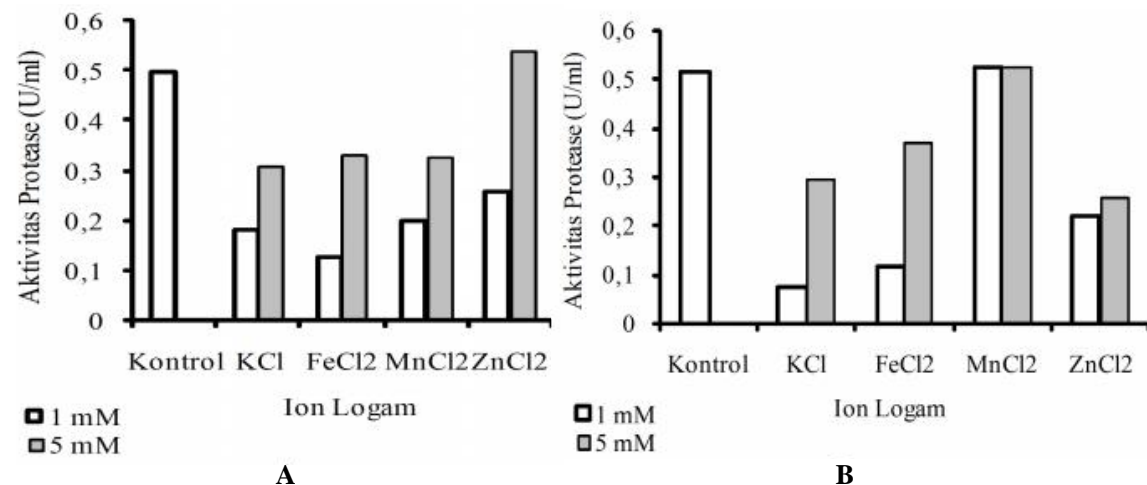

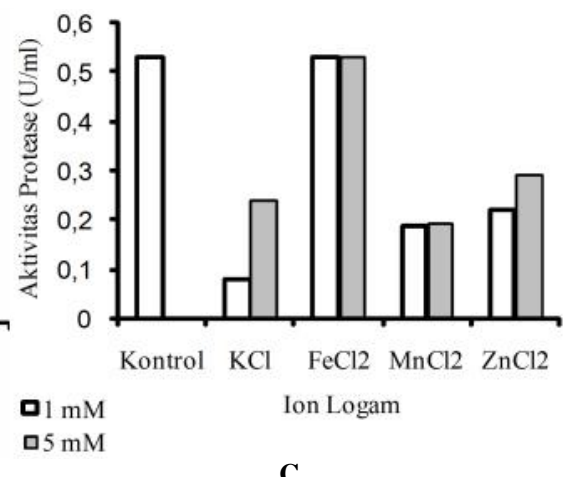

C

Gambar 4 Pengaruh ion logam pada protease dari bakteri air rawa $(\mathrm{A}=$ isolat $\mathrm{A} 6 \mathrm{~S} 3, \mathrm{~B}=\mathrm{A} 4 \mathrm{~S} 3$ dan $\mathrm{C}=\mathrm{A} 15 \mathrm{~S} 3)$ 
Protease memiliki kemampuan menghidrolisis substrat, maka Nomenclature Commite of International Union of Biochemistry and Moleculer Biology menggolongkan enzim protease ke dalam hidrolase. Sedangkan para ahli menggolongkan protease berbeda-beda. Berdasarkan mekanisme reaksi yang dikatalisis, endopeptidase dapat dikelompokkan menjadi empat yaitu: protease serin, protease aspartat, protease sistein dan protease logam. Dalam penelitian ini penggolongan protease hasil produksi dilakukan dengan cara mereaksikan dengan senyawasenyawa inhibitor spesifik. Adapun pengaruh inhibitor spesifik pada protease air rawa terdapat pada Tabel 2.

Tabel 2 menunjukkan EDTA (1mM dan $5 \mathrm{mM}$ ) dapat menghambat protease isolat bakteri air rawa, Hal ini dimungkinkan karena EDTA mengkelat logam-logam yang berperan penting menjaga stabilitas serta logam yang berperan sebagai kofaktor enzim protease. Oleh karena protease ini dihambat oleh EDTA sehingga protease ini digolongkan sebagai metaloprotease (protease logam). Protease bakteri lain yang termasuk metalloprotease adalah Alteromonas sp O-7 (Miyamoto et al. 2002).

Penentuan Berat Molekul dengan SDS PAGE dan Zimogram. Hasil SDS-PAGE dan Zimogram protease isolat bakteri air dapat dilihat pada Gambar 5. Analisis SDS-PAGE pada protease ekstrak kasar didapatkan protease untuk isolat

Tabel 2 Pengaruh inhibitor spesifik pada protease bakteri air rawa

\begin{tabular}{lcc}
\hline \multirow{2}{*}{ Jenis bakteri } & \multicolumn{2}{c}{$\begin{array}{c}\text { Aktivitas residu }(\%) \\
\text { EDTA }\end{array}$} \\
\cline { 2 - 3 } & $1 \mathrm{mM}$ & $5 \mathrm{mM}$ \\
\hline A6S3 & 19,6 & 18,9 \\
A4S3 & 57,9 & 12,6 \\
A15S3 & 0 & 23,1 \\
\hline
\end{tabular}

A6S3 memiliki 12 pita dengan BM berkisar antara $19 \mathrm{kD}$ sampai dengan $153 \mathrm{kD}$, isolat A4S6 memiliki 8 pita dengan MB berkisar antara $29 \mathrm{kD}$ sampai dengan $138 \mathrm{kD}$ dan isolat A15S3 memiliki 6 pita dengan MB berkisar antara $18 \mathrm{kD}$ sampai dengan $131 \mathrm{kD}$. Analisis Zimogram pada protease ekstrak kasar didapatkan protease untuk isolat A6S3 memiliki 4 pita dengan $\mathrm{BM} 70 \mathrm{kD}, 88 \mathrm{kD}, 106 \mathrm{kD}$ dan $121 \mathrm{kD}$, isolate A4S3 memiliki 1 pita dengan berat molekul $138 \mathrm{kD}$ dan isolat A15S3 memiliki 1 pita dengan berat molekul $131 \mathrm{kD}$. Beberapa berat molekul protease lain adalah $B$. pumilus memiliki berat molekul 28 kD (Kumar 2002), Halobacillus sp. SR5-3 berat molekulnya 43 kD (Namwong et al. 2006), Yersinia ruckeri berat molekulnya 47 kD (Secades \& Guijarro 1999), Alcaligenes faecalis berat molekulnya $67 \mathrm{kD}$ (Thagam \& Rajkumar 2002), dan Heliobacter pyori memiliki berat molekul yang tinggi yaitu 200 kD (Windle \& Kelleher 1997).

\section{SIMPULAN}

Protease isolat A6S3, A4S3 dan A15S3 memiliki waktu produksi optimum adalah $16 \mathrm{jam}, \mathrm{pH}$ optimum isolat $\mathrm{A} 6 \mathrm{~S} 3$ dan A15S3 adalah 8, dan isolat A4S3 adalah 7,5. Suhu optimum protease $\mathrm{A} 4 \mathrm{~S} 3$ adalah $40^{\circ} \mathrm{C}$ dan isolat $\mathrm{A} 6 \mathrm{~S} 3$ dan $\mathrm{A} 15 \mathrm{~S} 3$ adalah $50^{\circ} \mathrm{C}$. Inhibitor ion logam yang kuat terhadap protease adalah $\mathrm{Fe}^{2+}(1 \mathrm{mM})$ dan $\mathrm{K}^{+}$pada isolat $\mathrm{A} 6 \mathrm{~S} 3$, sedangkan protease isolat $\mathrm{A} 4 \mathrm{~S} 3$ inhibitor kuat adalah semua ion logam dengan konsentrasi $1 \mathrm{mM}$. Untuk protease isolat A15S3 inhibitor kuatnya adalah K (1 dan 5 mM), Mn (1 dan $5 \mathrm{mM}$ ) dan $\mathrm{Zn}$ (1 dan $5 \mathrm{mM}$ ). Semua protease dari isolat air rawa dihambat oleh EDTA. Analisis Zimogram pada protease ekstrak kasar didapatkan protease untuk isolat A6S3 memiliki 4 pita dengan $\mathrm{BM} 70 \mathrm{kD}, 88 \mathrm{kD}, 106 \mathrm{kD}$ dan $121 \mathrm{kD}$, isolat

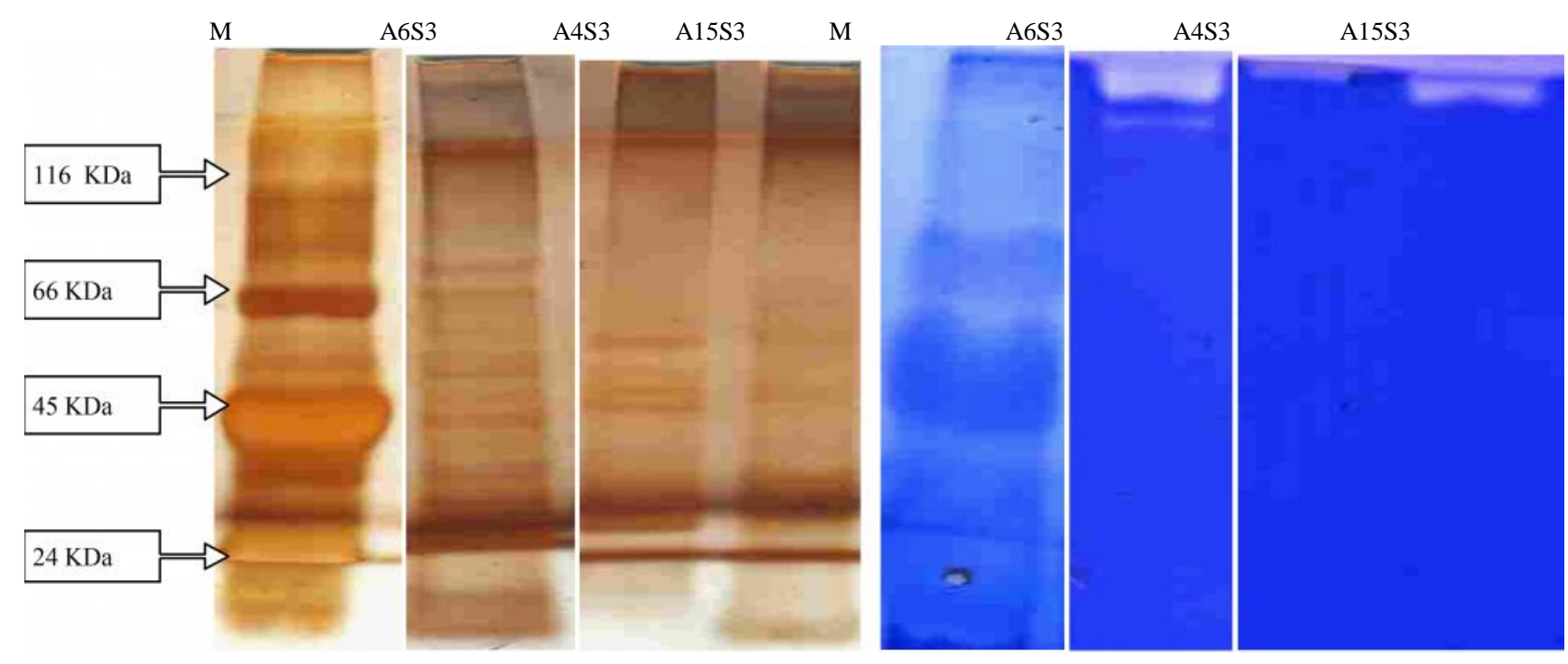

Gambar 5 Hasil SDS PAGE dan Zimogram protease isolat bakteri air rawa (M=marker) 
A4S3 memiliki 1 pita dengan berat molekul $138 \mathrm{kD}$ dan isolat A15S3 memiliki 1 pita dengan berat molekul $131 \mathrm{kD}$.

\section{UCAPANTERIMAKASIH}

Peneliti berterima kasih kepada Direktorat Jenderal Pendidikan Tinggi Depdiknas yang telah membiayai penelitian ini melalui program Hibah Bersaing tahun 2008 dan 2009 dengan no kontrak: 0200.0/023-04.2/VI/2009.

\section{DAFTAR PUSTAKA}

Adinarayana, K., Sllaiah, P \& Prasad, D.S. 2003. Production and partial characterization of thermostable serine alkaline protease from a newly isolated Bacillus subtilis PE-11. American Association of Pharmaceutical Scientists(AAPS) 4(4): E56-64.

Bergmeyer, H.U., Bergmeyer, J \& Graâl, M. 1983. Methods of Enzymatic Analysis. Vol 2. Weinheim : Verlag Chemie.

Choi, N.S., Yoon, K.S., Lee, J.Y., Han, K.Y \& Kim, S.H. 2001. Comparision of three substrates (casein, fibrin, and gelatin) in zimographic gel. J Biochem Mol Biol 34: 531-536.

Hames, B.D \& Hooper, N.M. 2000. Biochemistry: The Instant Notes. Ed.ke-2. Hongkong: Springer-Verlag.

Laemmli, U.K. 1970. Cleavage of structural protein during the assembly of the heat of bacteriophag T4. Nature 227: 680-685.

Kumar, C.G. 2002. Purification and characterization of thermostable alkaline protease from alkalophilic Bacillus pumilus. Lett Appl Microbiol 34: 13-17.

Miyamoto, K., Tsujibo, H., Nukui, E., Itoh, H., Kaidzu, Y \& Inamori Y. 2002. Isolation and characterization of the genes encoding two metalloproteases (MprI and MprII) from a marine bacterium, Alteromonas sp. strain O-7. Biosci Biotecnol Biochem 66: $416-21$.
Muchtadi, D., Palupi, N.S \& Astawan, M. 1996. Enzim dalam Industri Pangan. Bogor: PAU Pangan dan Gizi Institut Pertanian Bogor.

Namwong, S., Hiraga, K., Takada K., Tsunemi M., Tanasupawat, S \& Oda, K. 2006. A Halophilic serine proteinase from Halobacillus sp. SR5-3 isolated from fish sauce: purification and characterization. Biosci Biotechnol Biochem 70: 1395-1401.

Nascimento, W.C.A \& Martins, M.L.L. 2004. Production and properties of an extracellular protease from thermophilic Bacillus sp. Braz. J Microbiol 35: 91-96.

Olajuyigbe, F.M \& Ajele, J.O. 2008. Some properties of extracelullar protease from Bacillus licheniformis Lbbl-1 isolated from 'iru', a traditionally fermented African locust bean condiment. Glob J Biotechnol Biochem 3: 42-46.

Rao, M.M., Tanksale, A.M., Gatge, M.S \& Desphande, V.V. 1998. Molecular and biotechnological aspects of microbial proteases. Microbiol Mol Biol Rev 62: 597-635.

Richardson, T \& Hyslop, D.B. 1985. Enzyme. Di dalam: Fennema, O.R (Ed). Food Chemistry. New York: Mac Kerel Bekker, Inc.

Secades, P \& Guijarro. J.A. 1999. Purification and characterization of an extracellular protease from the fish pathogen Yirsinia ruckeri and effect of culture conditions on production. Appl Environ Microbiol 65: 3969-3975.

Suhartono, M.T. 1989. Enzim dan Bioteknologi. Bogor: Pusat Antar Universitas Bioteknologi IPB-Depdikbud.

Thangam, E.B \& Rajkumar G.S. 2002. Purification and characterization of alkaline protease from Alcaligenes faecalis. Biotechnol Appl Biochem 35: 149-154.

Tran, I.H \& Nagano, H. 2002. Isolation and characteristic of Bacillus subtilis $\mathrm{CN} 2$ and its collagenase production. J Food Sci 67: 1184-1187.

Usharani, B \& Muthuraj, M. 2010. Production and characterization of protease enzyme from Bacillus laterosporus. Afric J Microbiol Res 4: 1057-1063.

Van der Oost, J \& de Graff, L. 2003. Applied Moleculer Genetics. A Teaching Module. Wagening: Wagening University.

Windle, H.J \& Kelleher, D. 1997. Identification and characterization of a metalloprotease activity from Helicobacter pylori. Infect Immun 65: 3132-3137. 